\title{
Body indices and basic vital signs in Helicobacter pylori positive and negative persons
}

\author{
Marcela Kopáčová ${ }^{1}$, Jan Bureš ${ }^{1}$, Ilona Koupil ${ }^{2}$, Stanislav Rejchrt ${ }^{1}$, Viktor Voříšek ${ }^{3}$, \\ Bohumil Seifert ${ }^{4}$, Oldřich Pozler ${ }^{5}$, Pavel Živný ${ }^{3}$, Tomáš Douda ${ }^{1}$, Vladimír Palička ${ }^{3}$, \\ Jan Holčík ${ }^{6}$ \& the European Society for Primary Care Gastroenterology* \\ ${ }^{1}$ 2nd Department of Medicine, Charles University in Praha, Faculty of Medicine at Hradec Králové, University Teaching \\ Hospital, Sokolská 581, 500 05, Hradec Králové, Czech Republic; ${ }^{2}$ Centre for Health Equity Studies (CHESS), Stockholm \\ University, Karolinska Institutet, Stockholm, Sweden; ${ }^{3}$ Institute of Clinical Biochemistry and Diagnostics, Charles University \\ in Praha, Faculty of Medicine at Hradec Králové, University Teaching Hospital, Hradec Králové, Czech Republic; ${ }^{4}$ Institute of \\ General Practice, Charles University, First Faculty of Medicine, Praha, Czech Republic; ${ }^{5}$ Department of Paediatrics, Charles \\ University in Praha, Faculty of Medicine at Hradec Králové, University Teaching Hospital, Hradec Králové, Czech Republic; \\ ${ }^{6}$ Department of Social Medicine and Health Care Administration, Masaryk University, Faculty of Medicine, Brno, Czech \\ Republic
}

Accepted in revised form 17 November 2006

\begin{abstract}
It has been hypothesized that Helicobacter pylori $(\mathrm{Hp})$ infection may contribute to reduced stature, risk of hypertension or obesity. The aim was to evaluate body indices in $\mathrm{Hp}$ positive and negative persons. A total of 2436 subjects (4-100 years old) were tested for $\mathrm{Hp}$ status by ${ }^{13} \mathrm{C}$-urea breath test. Data on height and weight were collected for $84 \%$, and blood pressure for $80 \%$ of the study subjects. The prevalence of $\mathrm{Hp}$ infection was $41.6 \%$. The odds ratio for a 10-year increase in age was 1.21 (95\% CI 1.17$1.25, p$-value $<0.001)$. Statistically significant negative association of Hp positivity with body height was most pronounced in the younger age groups, while a
\end{abstract}

positive association of $\mathrm{Hp}$ positivity with body mass index was only seen in those aged $15+$ years. There was a negative effect of $\mathrm{Hp}$ positivity on systolic and diastolic blood pressure in subjects below 25 and a relatively strong positive effect on blood pressure in subjects over 65 years. Residual confounding by social characteristics as a possible explanation for the associations of $\mathrm{Hp}$ positivity with height and blood pressure cannot be excluded. Unmeasured factors related to social and family environment may cause the apparent association between $\mathrm{Hp}$ positivity and children's growth and blood pressure.

Key words: ${ }^{13} \mathrm{C}$-urea breath test, Height, Helicobacter pylori, Hypertension, Weight

\section{Introduction}

Helicobacter pylori $(\mathrm{Hp})$ has been recognized as one of the most common chronic bacterial infection in the world. Its prevalence is high in developing

*The European Society for Primary Care Gastroenterology, participants in the Project: Eva Jančová, MD (Praha 4), Václav Hanka, MD (Nové Město nad Metují), Miloš Ponížil, MD (Hrušovany nad Jevišovkou), Karel Janík, MD (Horní Bečva), Tomáš Koudelka, MD (Počátky), Irena Holdšvendová, MD (Aš), Jiří Appelt, MD (Chýně), Romana Balatková, MD (Most), Jiřina Šrůtková, MD (Hradec Králové), Marcela Charvátová, MD (Ostrava, Poruba), Bohumil Seifert, MD (Rudná), Gréta Koudelková, MD (Žatec), Miroslava Šircová, MD (Slaný), Irena Bumbová, MD (Kamenné Žehrovice), Otto Herber, MD (Veltrusy), Eva Charvátová, MD (Praha 5), Šárka Čermáková, MD (Slaný), Olga Kliková, MD (Praha 10) and Jarmila Seifertová, MD (Kladno) countries (80-90\%) and lower in developed ones $(<40 \%)[1,2]$. Hp infection is acquired during early childhood in most individuals. The infection lasts several decades or even life long, with a low spontaneous eradication rate. $\mathrm{Hp}$ is a cause of chronic gastritis and may be closely associated with a number of extragastric diseases [2, 3]. In general, any chronic inflammatory conditions can influence health status remote to the site of inflammation. It has been suggested that chronic Hp infection may predispose subjects to the development of malnutrition [4, 5] and growth delay in children [4-7]. On the other hand it has been hypothesized that chronic $\mathrm{Hp}$ infection may contributed to hypertension [8-11], lipid metabolism disturbance [9, 12] and obesity [9]. However, published results are rather controversial in current literature. Other authors have found no association of $\mathrm{Hp}$ infection or short stature [13-15], hypertension [16, 17], nutritional 
status $[15,18]$ or obesity $[19,20]$. These papers are difficult to be compared as they differ in the individuals studied, design and number of subjects, the diagnostic methods used (serology, ${ }^{13} \mathrm{C}$-urea breath test, stool antigen tests) and coming from both developed and developing countries. The Czech Republic has medium prevalence of Helicobacter pylori infection $(\sim 40 \%)$ and thus differs from both developed and developing countries. The aim of this study was to evaluate body indices and basic vital signs in $\mathrm{Hp}$ positive and negative persons in a representative sample of the general Czech population.

\section{Subjects and methods}

\section{Subjects}

Hp status was investigated in 2436 persons older than 4 years. These subjects were chosen in a two-step random selection, carried out centrally, in a general population of 30,012 individuals. Nineteen general practitioners (12 for adults and 7 for children) took part in this Project. Recruitment areas fitted well with geographic distribution of population in the Czech Republic, covering cities and towns (8 GPs), smaller towns with surrounding villages (8 GPs) and rural areas (3 GPs). There were no preliminary exclusion criteria.

For $2425(>99.5 \%)$ of these, results of two test samples were available. For the purpose of the current analysis 1,003 subjects who had positive results in both tests or one positive and one borderline (or missing) result are classified as Hp positive. Twentyfive $(<1 \%)$ subjects with clearly discrepant results (one positive and one negative) were excluded from the evaluation. The rest of the study subjects are considered Hp negative for the purpose of the current analysis.

\section{Urea breath test}

Urea breath tests were performed in the morning after overnight fasting. Citric acid solution (3 g dissolved in $150 \mathrm{ml}$ of still water) was used as a test drink. All subjects ingested $100 \mathrm{mg}{ }^{13} \mathrm{C}$-urea for adults (Helicobacter Test Hp Plus, Utandningstester i Sverige AB, Göteborg, Sweden) or $75 \mathrm{mg}{ }^{13} \mathrm{C}$-urea for children and adolescents (Helicobacter Test INFAI, INFAI GmbH, Köln, Germany) dissolved in $50 \mathrm{ml}$ of still water with $1 \mathrm{~g}$ citric acid. Baseline and test breath samples were collected in duplicate at time 0 and after $30 \mathrm{~min}$. Tubes with breath samples were sent to a single analytical centre by post and measured within a 1-week period. Breath samples were analysed by means of isotope ratio mass spectrometry (AP 2003, Analytical Precision, United Kingdom). Cut-off was 3.5 (grey zone range 3.3-3.7).

\section{Body indices and basic vital signs}

Data on height and weight were collected at the clinics for $84 \%$ of the study subjects. Overweight and obesity in adults were defined as body mass index of $25+$ and $30+\mathrm{kg} / \mathrm{m}^{2}$, respectively. The definitions of overweight and obesity in children and adolescents aged 4-17 years are based on age and gender-specific cut-off points developed by Cole et al. [21].

Systolic and diastolic blood pressure measurements were performed by a trained nurse in a standard manner [22] at the study clinics and were completed for $80 \%$ of the study subjects. The blood pressure was measured in the morning (from 8 to 12 a.m.). Hypertension in adults was defined as systolic blood pressure $\geq 140$ and/or diastolic blood pressure $\geq 90 \mathrm{~mm} \mathrm{Hg}$, according to the guidelines of European Society of Hypertension-European Society of Cardiology [22] and the reviewed WHOInternational Society of Hypertension guidelines [23]. Hypertension in children and adolescents aged 4-17 years was defined based on the age, gender and height-specific criteria published by the National High Blood Pressure Education Program Working Group on High Blood pressure in Children and Adolescents (2004) [24]. Analyses of associations of Hp positivity with body size and blood pressure were restricted to $79.8 \%$ of the sample with data on height, weight, systolic and diastolic blood pressure available. There were no statistically significant differences in the prevalence of $\mathrm{Hp}$ positivity, age, gender or nationality between the subjects with all data available and those who had missing data on body size or blood pressure. The subjects excluded from the analyses because of missing data on body size or blood pressure tended, however, to be on average more educated and were more likely to live in large towns.

\section{Questionnaires}

Social characteristics are based on data from selfcompleted questionnaires and include nationality classified as Czech and other, place of residence classified as "village", "small town with less than 20,000 inhabitants" and "larger town with more than 20,000 inhabitants" and highest level of education achieved. The study subjects' own education or their parents' education (if younger than 25 years or still studying) are analysed as categorical variables with four categories (basic or less, vocational training, secondary education, university). Information on social characteristics was available for $99 \%$ of the study sample. Information on the study subjects' smoking habits was also collected in the questionnaire, grouped into three categories of "never", "past" and current" smokers, and is used in the analyses for those aged $15+$. 


\section{Statistical analysis}

The data was analysed by univariate and multivariate linear and logistic regressions as appropriate, using the STATA package [25]. Multivariate analyses were restricted to those subjects with all relevant data available. Results of analyses stratified by age are presented in this paper to take account of the hypothesised interactions with age of the study subjects.

\section{Study approval and confidentiality of data obtained}

The study was approved by the local Ethics committee. All participants got detailed written information about the Project in advance and signed written consent (parents on behalf of their children). For all data obtained, all personal identification information was deleted in compliance with the laws for the protection of confidentiality of the Czech Republic.

\section{Results}

Basic descriptive characteristics of the study sample are presented in Table 1. The overall prevalence of Hp positivity in our study was $41.6 \%$. Hp positivity was strongly associated with age of the study subjects. The odds ratio for a 10-year increase in age was 1.21 (95\% CI 1.17-1.25, $p$-value <0.001). There were no statistically significant gender differences in $\mathrm{Hp}$ positivity. The age-adjusted odds ratio for $\mathrm{Hp}$ positivity in females compared to males was $0.95(95 \% \mathrm{CI}$ $0.81-1.13, p$-value 0.577$)$. Only four subjects $(<0.2 \%)$ were on long term proton pump inhibitors treatment at the time of our study, of whom two subjects tested as $\mathrm{Hp}$ positive and two as $\mathrm{Hp}$ negative. Exclusion of these four subjects from analysis did not affect the results appreciably.

We observed a relatively strong and statistically significant negative association of Hp positivity with body height, which was most pronounced, and statistically significant, in the younger age groups (Table 2). Some of this association was explained by further adjustments for place of residence, education and nationality (Table 2).

Hp positivity was also associated with a slightly lower body mass index in children below 15 years (Table 2) and with a higher mean body mass index in subjects over 15 years (Table 2). The associations of Hp positivity with body mass index were relatively little affected by adjustments for social characteristics or smoking (Table 2).

Analyses of overweight and obesity showed a statistically significantly lower prevalence of overweight in $\mathrm{Hp}$ positive children and a higher prevalence of overweight and obesity in adults that was of borderline statistical significance (Table 3).

There were marked differences between age groups in how $\mathrm{Hp}$ positivity was related to systolic and diastolic blood pressure. We observed a strong negative effect of $\mathrm{Hp}$ positivity on systolic and diastolic blood pressure in subjects below 25 years of age and a relatively strong positive effect on blood pressure in subjects aged $65+$ years (Table 4 ). While the strength of the association between Hp positivity and blood pressure in children was nearly halved on adjustment for body mass index and social characteristics, the strength of the positive association between $\mathrm{Hp}$ positivity and blood pressure in oldest subjects was less affected by adjustments for body mass index, social characteristics and smoking, and the negative association between Hp positivity and blood pressure in subjects aged 15-24 became stronger.

Analyses of Hp positivity with hypertension yielded results broadly consistent with analyses of blood pressure (Table 5). Fully adjusted analyses did not show statistically significant associations between $\mathrm{Hp}$ positivity and hypertension, with the exception of a positive association of borderline statistical significance seen in the oldest group (Table 5). The statistical interactions of $\mathrm{Hp}$ positivity with age in their effect on blood pressure and hypertension were statistically significant, suggesting differential effects, and possibly also different mechanisms, by which $\mathrm{Hp}$ positivity is related to blood pressure in different age groups.

We did not observe any statistically significant effects of Hp positivity on pulse rate in any age group (data not shown).

\section{Discussion}

The overall prevalence of $\mathrm{Hp}$ infection was $41.6 \%$ in this study. Hp positivity was strongly associated with age of the study subjects. We observed a relatively strong and statistically significant negative association of $\mathrm{Hp}$ positivity with body height, which was most pronounced, and statistically significant, in the youngest age groups (Table 2). Several epidemiological studies showed association between Hp infection and short growth in children [4-7]. However, contradictory data are available on this topic, as other authors did not find any relation [13-15]. Results and conclusions of all published papers (including our findings) must be assessed with caution. It is necessary to distinguish intrinsic shortness and delayed or attenuated growth. Several factors can influence growth and stature, including chronic inflammation, nutrition and several gastrointestinal diseases [26].

Thomas et al. [4] followed 190 children in Gambia from their birth in two cohort studies. Early colonisation with $\mathrm{Hp}$ was associated with weight and growth deficit compared to non-infected individuals. No socioeconomic or demographic confounding variables were identified these findings. The deficit was no longer detectable when the children reached age of 5-8 years [4]. Bravo et al. [27] studied $347 \mathrm{Hp}$ 


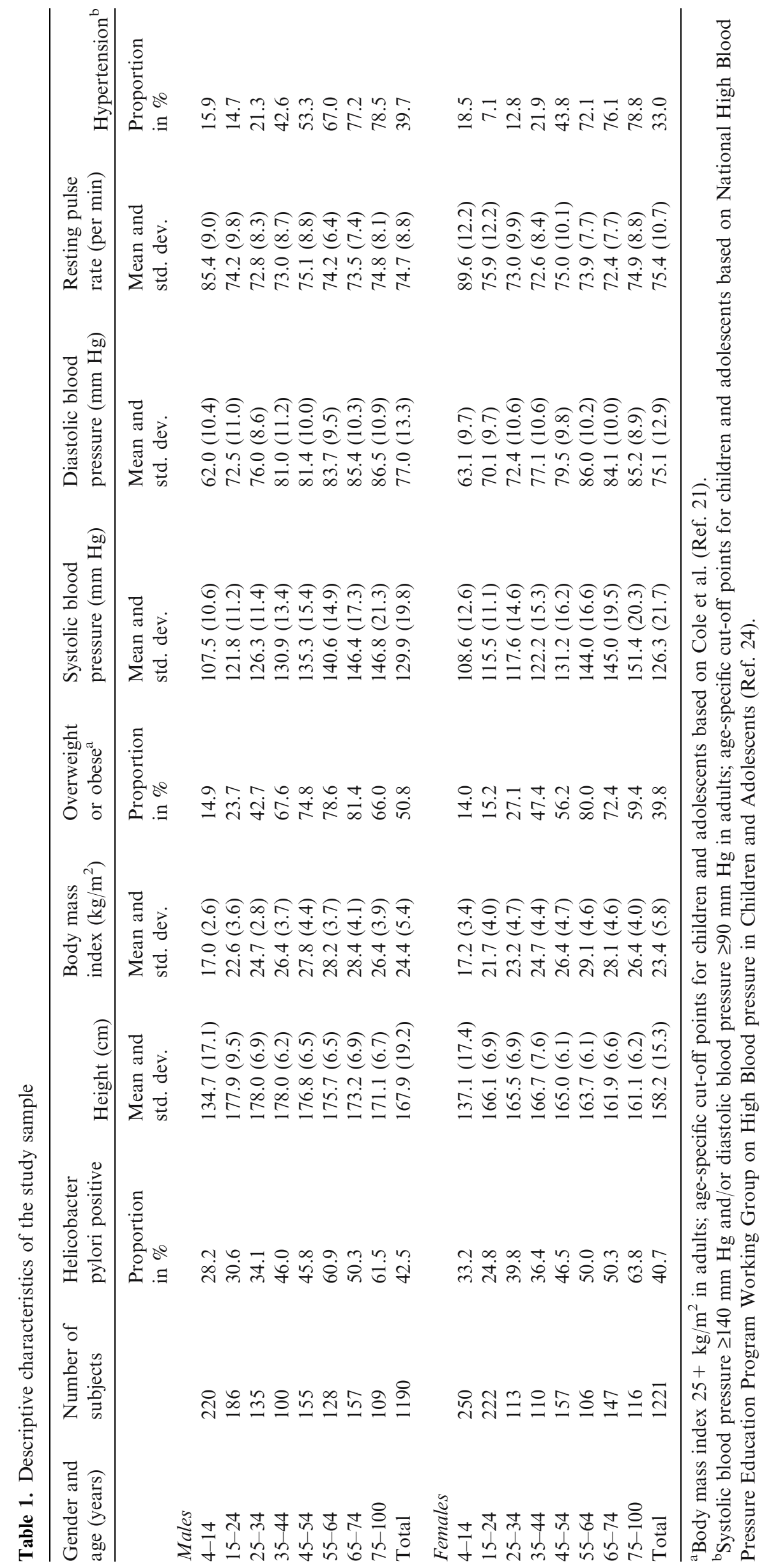



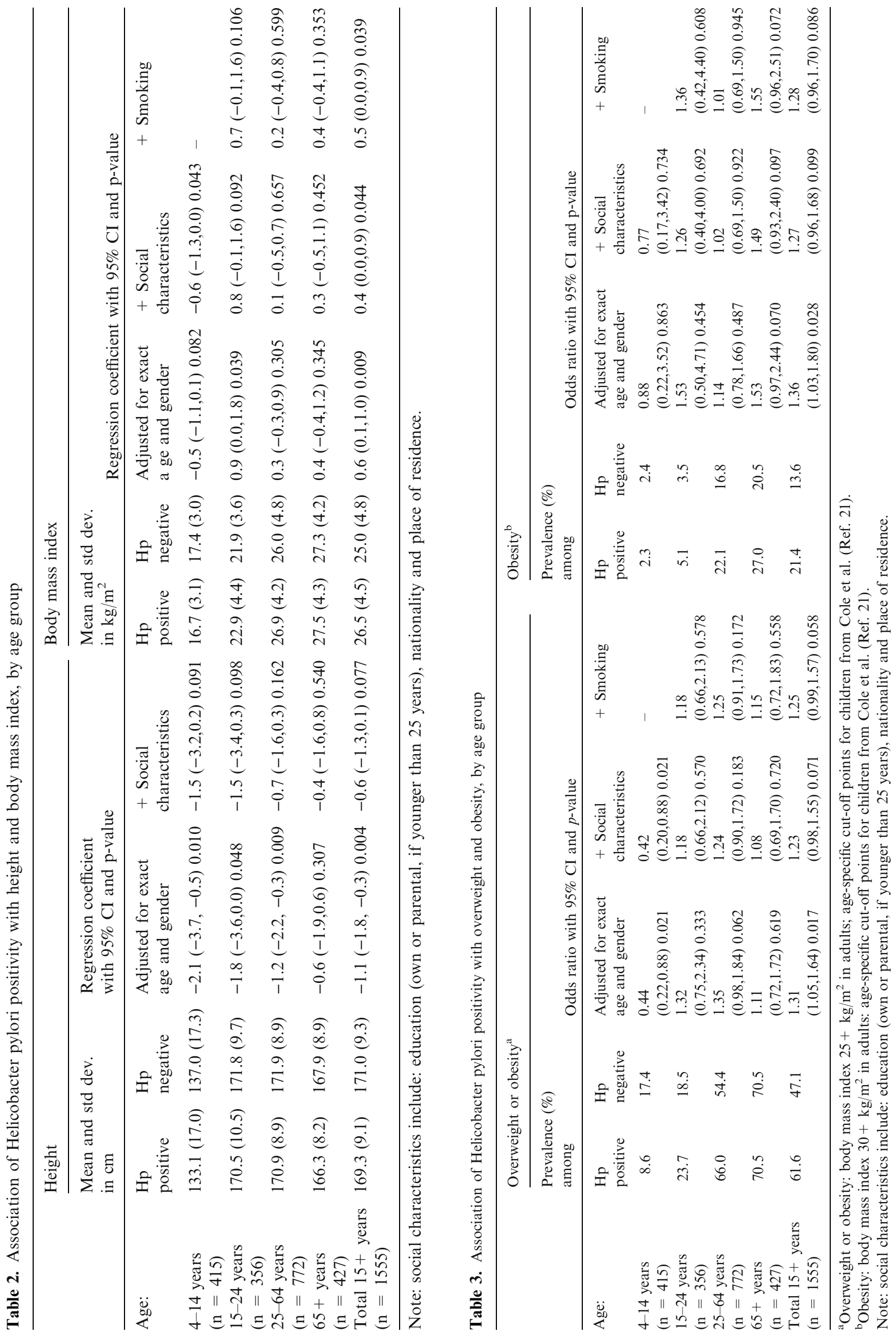


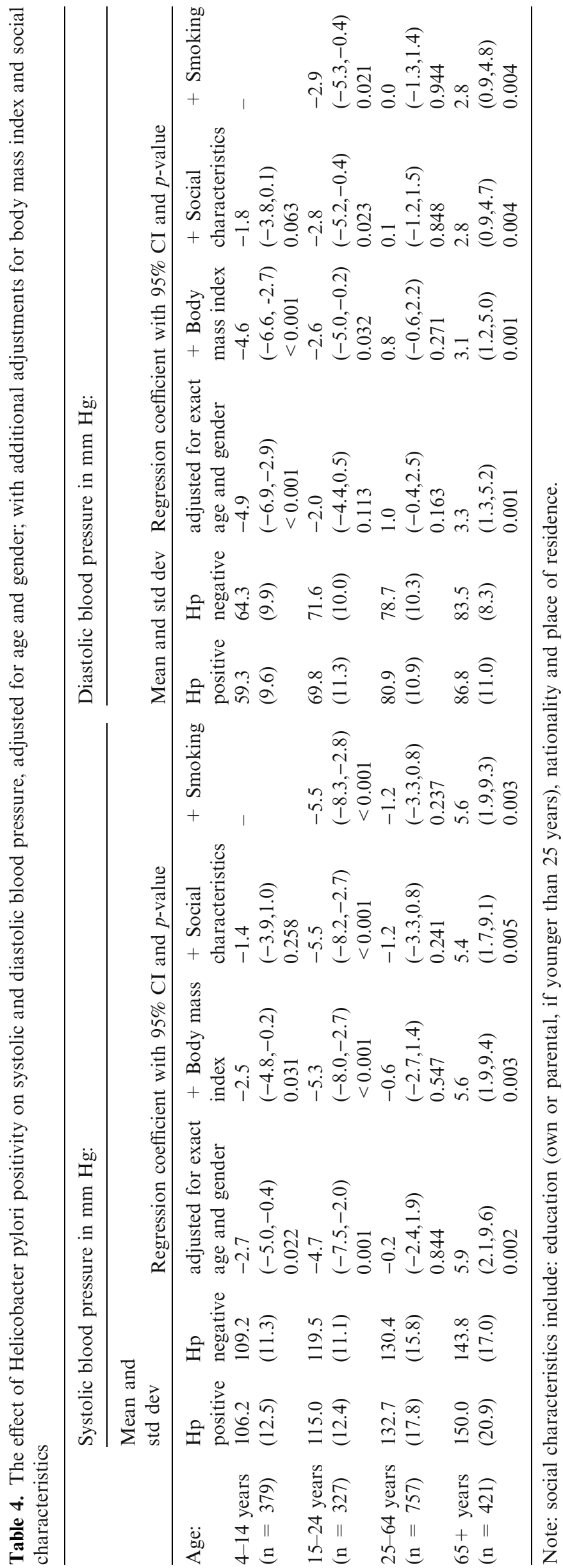


Table 5. The effect of Helicobacter pylori positivity on hypertension, adjusted for age and gender; with additional adjustments for body mass index and social characteristics

\begin{tabular}{|c|c|c|c|c|c|c|}
\hline \multirow[b]{3}{*}{ Age: } & \multicolumn{6}{|c|}{ Hypertension $^{\mathrm{a}}$} \\
\hline & \multicolumn{2}{|c|}{ Prevalence $(\%)$} & \multicolumn{4}{|c|}{ Odds ratio with $95 \% \mathrm{CI}$ and $p$-value } \\
\hline & $\begin{array}{l}\mathrm{Hp} \\
\text { positive }\end{array}$ & $\begin{array}{l}\text { Hp } \\
\text { negative }\end{array}$ & $\begin{array}{l}\text { Adjusted for exact } \\
\text { age and gender }\end{array}$ & $\begin{array}{l}+ \text { Body } \\
\text { mass index }\end{array}$ & $\begin{array}{l}+ \text { Social } \\
\text { characteristics }\end{array}$ & + Smoking \\
\hline $\begin{array}{l}4-14 \text { years } \\
(\mathrm{n}=379)\end{array}$ & 13.8 & 19.5 & $\begin{array}{l}0.65 \\
(0.36,1.19) 0.161\end{array}$ & $\begin{array}{l}0.68 \\
(0.37,1.24) 0.210\end{array}$ & $\begin{array}{l}0.72 \\
(0.37,1.38) 0.324\end{array}$ & - \\
\hline $\begin{array}{l}15-24 \text { years } \\
(\mathrm{n}=327)\end{array}$ & 10.1 & 10.5 & $\begin{array}{l}0.92 \\
(0.41,2.08) 0.852\end{array}$ & $\begin{array}{l}0.80 \\
(0.35,1.84) 0.601\end{array}$ & $\begin{array}{l}0.64 \\
(0.26,1.56) 0.326\end{array}$ & $\begin{array}{l}0.59 \\
(0.24,1.48) 0.264\end{array}$ \\
\hline $\begin{array}{l}25-64 \text { years } \\
(\mathrm{n}=757)\end{array}$ & 46.5 & 39.5 & $\begin{array}{l}1.02 \\
(0.74,1.40) 0.899\end{array}$ & $\begin{array}{l}0.96 \\
(0.69,1.34) 0.830\end{array}$ & $\begin{array}{l}0.86 \\
(0.61,1.21) 0.377\end{array}$ & $\begin{array}{l}0.84 \\
(0.60,1.19) 0.337\end{array}$ \\
\hline $\begin{array}{l}65+\text { years } \\
(\mathrm{n}=421)\end{array}$ & 81.6 & 72.7 & $\begin{array}{l}1.62 \\
(1.02,2.58) 0.041\end{array}$ & $\begin{array}{l}1.58 \\
(0.98,2.54) 0.058\end{array}$ & $\begin{array}{l}1.53 \\
(0.94,2.50) 0.089\end{array}$ & $\begin{array}{l}1.56 \\
(0.95,2.56) 0.076\end{array}$ \\
\hline
\end{tabular}

${ }^{a}$ Systolic blood pressure $\geq 140 \mathrm{~mm} \mathrm{Hg}$ and/or diastolic blood pressure $\geq 90 \mathrm{~mm} \mathrm{Hg}$ in adults; age-specific cut-off points for children and adolescents based on National High Blood Pressure Education Program Working Group on High Blood pressure in Children and Adolescents (Ref. 24).

Note: social characteristics include: education (own or parental, if younger than 25 years), nationality and place of residence.

negative children aged $12-60$ months (tested by ${ }^{13} \mathrm{C}$ urea breath test). During the prospective follow-up (2.5 years) $105(30 \%)$ children, who were uninfected at the start of the study, acquired $\mathrm{Hp}$ infection. Growth velocity in infected children was significantly reduced $(0.5 \mathrm{~cm}$ per year) [27]. Passaro et al. [28] found that even 2 months after eradication of $\mathrm{Hp}$ (assessed by seroconversion) there was a slowing of weight gain in young children. Reasons for this finding remain unclear. However, Naficy et al. [15] did not find such an association among young seroconverted Egyptian children. Hp infection was not associated with malnutrition either [15]. In a study from Guatemala [18], 211 girls aged 5-10 were investigated and their height-for-age was significantly decreased with both $\mathrm{Hp}$ infection and lower income level. However, Hp infection did not affect nutritional status of those individuals [18]. Sood et al. [29] having assessed 257 children in a US study, found $\mathrm{Hp}$ positive children shorter and lighter compared with non-infected ones. They concluded that differences in anthropometry might be due to socioeconomic and ethnic factors rather that Hp infection [29].

Perri et al. [7] found a strong relationship between $\mathrm{Hp}$ infection and short stature in older children, poor socio-economic status and household overcrowding. Several hypotheses were given to explain this association: chronic systemic release of cytokines (tumour necrosis factor alfa in particular) affecting growth, low energy intake and/or malnutrition and low socioeconomic background may be the pathogenic mechanisms responsible for short stature [7]. Choe et al. [30] found a significantly lower height among 532 healthy children aged 10-15 having both $\mathrm{Hp}$ infection and iron deficiency anaemia. Authors concluded that $\mathrm{Hp}$ infection accompanied by iron deficiency anaemia, rather than $\mathrm{Hp}$ infection per se, might delay pubertal growth [30]. According to other studies both Hp infection and short stature are two non-related consequences of low socio-economic status [16]. Growth delay at around the time of puberty in $\mathrm{Hp}$ positive children was also found by other authors $[6,7,31,32]$ and could be explained as delayed pubertal growth spurting. Delayed menarche in Hp positive girls [33] is consistent with these findings. Recently, Moayyedi et al. [34] found that $\mathrm{Hp}$ infected women (aged 40-49) were $1.4 \mathrm{~cm}$ shorter than uninfected ones. Statistically significant difference persisted even after adjusting for age, ethnicity, childhood and present socio-economic status. Despite this, authors concluded that this reduced adult height might be due to residual confounding [34]. Similar findings of reduced height in Hp positive women (but not men) compared to $\mathrm{Hp}$ negative ones were described also by Murray et al. [35]. In this large population-based study (4742 subjects aged 12-64) Hp was more common in men (61\%) than women $(55 \%)$ [35].

In our study, Hp positivity was associated with a slightly lower body mass index in children below 15 years and with a higher mean body mass index and a higher prevalence of overweight and obesity in older subjects. In literature, there are both positive [9, $33]$ and negative $[19,20]$ reports on association of $\mathrm{Hp}$ infection and higher body mass index and/or obesity. $\mathrm{Hp}$ eradication has induced increase in body mass index in Japanese industrial workers [36]. According to another studies, $\mathrm{Hp}$ eradication improved some nutritional parameters, including gain in body weight [37].

We have also found marked differences between age groups in how Hp positivity was related to systolic and diastolic blood pressure. We observed a strong negative effect of $\mathrm{Hp}$ positivity on systolic and diastolic blood pressure in subjects below 25 years of age and a relatively strong positive effect on blood 
pressure in subjects over 65-year old (Tables 4 and 5). Controversial data have been published in literature on the association of $\mathrm{Hp}$ infection and hypertension with both positive [8-11] and negative $[16,17]$ results. In a large community-based cross sectional study (1634 Hp positive and $3267 \mathrm{Hp}$ negative persons out of 10,537 subjects enrolled), Hp infection had little effect on blood pressure in the general population, mean systolic blood pressure was higher in $\mathrm{Hp}$ infected individuals than in those who were not infected and, although this was significant statistically, the authors concluded that it was unlikely to be clinically important and might be explained by unknown residual confounding factors [17]. Migneco et al. [10] demonstrated a significant decrease in blood pressure values (in particular in the diastolic one) after successful $\mathrm{Hp}$ eradication. There are several methodological difficulties in carrying out studies to determine possible relationship between $\mathrm{Hp}$ infection and raised blood pressure, there are several other factors that must be considered (weight gain, salt intake, aging, co-morbidity, antihypertensive therapy, compliance of patients etc.) [38]. We can speculate that a negative effect of $\mathrm{Hp}$ infection on blood pressure is markedly expressed (in the relative absence of other factors) in younger adults while other factors mentioned above dictate blood pressure in older subjects, both $\mathrm{Hp}$ positive and negative.

We cannot exclude residual confounding by social characteristics as a possible explanation for the associations of $\mathrm{Hp}$ positivity with height and blood pressure reported in our paper, especially in children. It is plausible that unmeasured factors related to social and family environment may cause the apparent association between Hp positivity and children's growth and blood pressure. On the other hand, associations of $\mathrm{Hp}$ positivity with overweight and hypertension in older subjects seem relatively little affected by adjustments for social characteristics or smoking in our study, and the respective underlying mechanisms should be further explored.

\section{Acknowledgement}

The Study was supported by the research project MZO 00179906 from the Ministry of Health, Czech Republic.

\section{References}

1. Perez-Perez GI, Rothenbacher D, Brenner H. Epidemiology of Helicobacter pylori infection. Helicobacter 2004; 9(Suppl 1): 1-6.

2. Kikuchi S, Dore MP. Epidemiology of Helicobacter pylori infection. Helicobacter 2005; 10(Suppl 1): 1-4.
3. Permin H, Andersen LP. Inflammation, immunity, and vaccines for Helicobacter infection. Helicobacter 2005; 10(Suppl 1): 21-25.

4. Thomas JE, Dale A, Bunn JE, Harding M, Coward WA, Cole TJ, Weaver LT. Early Helicobacter pylori colonisation: the association with growth faltering in Gambia. Arch Dis Child 2004; 89: 1149-1154.

5. Elitsur Y, Yahav J. Helicobacter pylori infection in pediatrics. Helicobacter 2005; 10(Suppl 1): 47-53.

6. Patel P, Mendall MA, Khulusi S, Northfiel TC, Strachan DP. Helicobacter pylori infection in childhood: risk factors and effect on growth. Br Med J 1994; 309: 1119-1123.

7. Perri F, Pastore M, Leandro G, Clemente R, Ghoos Y, Peeters M, Anesse V, Quitadamo M, Latiano A, Rutgeerts P, Andriulli A. Helicobacter pylori infection and growth delay in older children. Arch Dis Child 1997; 77: 46-49.

8. Beevers DG, Lip GY, Blann AD. Salt intake and Helicobacter pylori infection. J Hypertens 2004; 22: 1475 1477.

9. Ekesbo R, Nilsson PM, Lindholm LH, Persson K, Wadström T. Combined seropositivity for H. pylori and $C$. pneumoniae is associated with age, obesity and social factors. J Cardiovasc Risk 2000; 7: 191-195.

10. Migneco A, Ojetti V, Specchia L, Franceschi F, Candelli M, Mettima M, Montebelli R, Savi L, Gasbarrini G. Eradication of Helicobacter pylori infection improves blood pressure values in patients affected by hypertension. Helicobacter 2003; 8: 585-589.

11. Lip GH, Wise R, Beevers G. Association of Helicobacter pylori infection with coronary heart disease. Study shows association between $\mathrm{H}$ pylori infection and hypertension. Br Med J 1996; 312: 250-251.

12. Laurila A, Bloigu A, Nayha S, Hassi J, Leinonen M, Saikku P. Association of Helicobacter pylori infection with elevated serum lipids. Atherosclerosis 1999; 142: 207-210.

13. Vaira D, Menegatti M, Salardi S, Ali A, Altomare Stella F, Figura N, Landi F, Holton J, Farinelli S, Cuccaro V, Miglioli M, Cacciari E. Helicobacter pylori and diminished growth in children: is it simply a marker of deprivation? Ital J Gastroenterol Hepatol 1998; 30: 129-133.

14. Cacciari E, Menegatti M, Salardi S, Ali A, Stella FA, Figura N, Landi F, Holton J, Farinelli S, Cuccaro V, Miglioli M, Vaira D. Helicobacter pylori infection and cytotoxic antigen associated gene "A" status in short children. J Pediatr Endocrinol Metab 1999; 12: 197-201.

15. Naficy AB, Frenck RW, Abu-Elyazeed R, Kim Y, Rao MR, Savarino SJ, Wierzba TF, Hall E, Clemens JD. Seroepidemiology of Helicobacter pylori infection in a population of Egyptian children. Int J Epidemiol 2000; 29: 928-932.

16. Woodward M, Morrison C, McColl K. An investigation into factors associated with Helicobacter pylori infection. J Clin Epidemiol 2000; 53: 175-181.

17. Harvey R, Lane A, Murray L, Harvey I, Nair P, Donovan J. Effect of Helicobacter pylori infection on blood pressure: a community based cross sectional study. Br Med J 2001; 323: 264-265.

18. Quiñonez JM, Chew F, Torres O, Bégué RE. Nutritional status of Helicobacter pylori-infected children in 
Guatemala as compared with uninfected peers. Am J Trop Med Hyg 1999; 61: 395-398.

19. Kyriazanos ID, Sfiniadakis I, Gizaris V, Hountis P, Hatziveis K, Dafnopoulou A, Datsakis K. The incidence of Helicobacter pylori infection is not increased among obese young individuals in Greece. $\mathbf{J}$ Clin Gastroenterol 2002; 34: 541-546.

20. Cho I, Blaser MJ, Francois F, Mathew JP, YE XY, Goldberg JD, Bini EJ. Helicobacter pylori and overweight status in the United States: data from the Third National Health and Nutrition Examination Survey. Am J Epidemiol 2005; 162: 579-584.

21. Cole TJ, Bellizzi MC, Flegal KM, Dietz Wh. Establishing a standard definition for child overweight and obesity worldwide: international survey. $\mathrm{Br}$ Med $\mathrm{J}$ 2000; 320: 1240-1243.

22. Guidelines Committee. European Society of Hypertension-European Society of Cardiology guidelines for the management of arterial hypertension. J Hypertens 2003; 21: 1011-1053.

23. World Health Organization, International Society of Hypertension Writing Group. World Health Organization (WHO)/International Society of Hypertension (ISH) statement on management of hypertension. J Hypertens 2003; 21: 1983-1992.

24. National High Blood Pressure Education Program Working Group on High Blood Pressure in Children and Adolescents. The Fourth Report on the Diagnosis, Evaluation, and Treatment of High Blood Pressure in Children and Adolescents. Pediatrics 2004; 114: 555576.

25. StataCorp. Stata Reference Manual. Release 7.0. College Station, Texas: Stata Press, 2001.

26. Rogol AD. Causes of short stature. UpToDate online, vol 14.1. Wellesley, 2006.

27. Bravo LE, Mera R, Reina JC, Pradilla A, Altaze A, Fontham E, Correa P. Impact of Helicobacter pylori infection on growth of children: A prospective cohort study. J Pediatr Gastroenterol Nutr 2003; 37: 614-619.

28. Passaro DJ, Taylor DN, Giman RH, Cabrera L, Parsonnet J. Growth slowing after acute Helicobacter pylori infection is age-dependent. J Pediatr Gastroenterol Nutr 2002; 35: 522-526.

29. Sood MR, Joshi S, Akobeng AK, Mitchell J, Thomas AG. Growth in children with Helicobacter pylori infection and dyspepsia. Arch Dis Child 2005; 90: 1025-1028.

30. Choe YH, Kim SK, Hong YC. Helicobacter pylori infection with iron deficiency anaemia and subnormal growth at puberty. Arch Dis Child 2000; 82: 136-140.

31. Buyukgebiz A, Dundar B, Bober E, Buyukgebiz B. Helicobacter pylori infection in children with constitutional delay of growth and puberty. J Pediatr Endocrinol Metab 2001; 14: 549-551.

32. Yang YJ, Sheu BS, Lee SC, Yang HB, Wu JJ. Children of Helicobacter pylori-infected dyspeptic mothers are predisposed to $\mathrm{H}$. pylori acquisition with subsequent iron deficiency and growth retardation. Helicobacter 2005; 10: 249-255.

33. Rosenstock SJ, Jorgensen T, Anderson LP, Bonnevie O. Association of Helicobacter pylori infection with lifestyle, chronic disease, body-indices, and age at menarche in Danish adults. Scand J Public Health 2000; 28: 32-40.

34. Moayyedi P, Forman D, Duffett S, Mason S, Brown J, Crocombe W, Feltbower R, Axon A. Leeds HELP Study Group. Association between Helicobacter pylori infection and adult height. Eur J Epidemiol 2005; 20: 455-465.

35. Murray LJ, McCrum EE, Evans AE, Bamford KB. Epidemiology of Helicobacter pylori infection among 4742 randomly selected subjects from Northern Ireland. Int J Epidemiol 1997; 26: 880-887.

36. Azuma T, Suto H, Ito Y, Muramatsu A, Ohtani M, Dojo M, Yamazaki Y, Kuriyama M, Kato T. Eradication of Helicobacter pylori infection induces an increase in body mass index. Aliment Pharmacol Ther 2002; 16(Suppl 2): 240-244.

37. Furuta T, Shirai N, Xiao F, Takashima M, Hanai H. Effect of Helicobacter pylori infection and its eradication on nutrition. Aliment Pharmacol Ther 2002; 16: 799-806.

38. Kaplan NM, Rose BD. Obesity and weight reduction in hypertension. UpToDate online, vol 14.1. Wellesley, 2006.

Address for correspondence: Marcela Kopáčová, MD, PhD, 2nd Department of Medicine, Charles University in Praha, Faculty of Medicine at Hradec Králové, University Teaching Hospital, Sokolská 581, 500 05, Hradec Králové, Czech Republic

Phone: + 420-495-833818; Fax: + 420-495-834785

E-mail: kopacmar@fnhk.cz 